\title{
Descriptive, Correlation Analysis and Analytical Hierarchy Process of Coastal Community Empowerment of Bengkulu City, Indonesia
}

\author{
Indra Cahyadinata $^{\mathrm{a}, 1}$, Nusril ${ }^{\mathrm{a}}$, Gushevinalti ${ }^{\mathrm{b}}$ \\ ${ }^{a}$ Department of Agribusiness, University of Bengkulu, Jl. WR. Supratman, Bengkulu, 38371, Indonesia \\ E-mail: ${ }^{1}$ cahyadinata@unib.ac.id
}

${ }^{b}$ Department of Communication Science, University of Bengkulu, Jl. WR. Supratman, Bengkulu, 38371, Indonesia

\begin{abstract}
The Coastal Community Economic Empowerment is one of the programs meant to boost the economy of coastal communities. The program is beneficial in several ways, such as increasing capital and fulfilling the daily needs of households. This study aimed to 1) assess the rate of community participation and the related factors, 2) determine cooperative performance rate, and 3) formulate alternative strategies for developing economic empowerment for the coastal community. To achieve these goals, 61 respondents and 15 experts were selected from Coastal Community Development Cooperative and its customers. The analytical tools used include descriptive and correlation analysis, analysis of institutional performance, and analytical hierarchy process. The results showed that the overall participation of cooperative members was in the high category while their involvement in meetings was in the moderate category. Also, the participation of members in loan repayment and fulfilling their obligation were in the high category. Family income and business experience affect the participation of members. The institution's performance was very healthy, especially in the organization, management, and financial administration. Besides, the development strategy aimed to enhance the business, increase competitiveness, and improve the income of the coastal community. For this reason, the approach used includes optimizing the utilization of resources, provision of capital for cooperatives, and contributing income to the households. There were also alternative strategies, including business diversification, institutional strengthening, and improved access to capital. The priority strategy was the strengthening of the cooperative to increase competitiveness, while the success criteria involved the optimization of resource usage.
\end{abstract}

Keywords — coastal community; empowerment; development strategy.

\section{INTRODUCTION}

Bengkulu is one of the provinces that are adjacent to the Indian Ocean, with a coastline of $525 \mathrm{~km}$ [1]. It is the provincial capital and the only city in the entire province. It is the smallest area but has the highest population compared to other Districts in the Province. Almost all the areas in Bengkulu coastal region have an altitude above sea level, specifically between $0-20$ meters [2]. About 80 percent of the coastal community in the city work in the agricultural sector, particularly in fisheries and marine.

In general, the development of fisheries and marine in the past lacked attention from the government. As a result, the problems faced by the coastal communities were passed from generation to another. One indication of the lack of government attention was the limited access to financial capital and a small amount of bank credit allocated to fishery activities and marine, individually 0.02 percent of total loans [3]. Therefore, it was common for coastal communities were poor, underdeveloped, and marginalized.
A similar situation is also found in other developing countries, such as in Sorsogon and Calaguas Island of the Philippines [4] [5]. Fishing dependent communities in these areas are vulnerable to climate change and related disasters due to limited access to financial capital and high poverty levels. For instance, poverty in coastal communities of Tanzania and Zanzibar is attributed to inadequate access to land assets, markets, and education [6].

To improve the economy of coastal communities, the government established a program called coastal community economic empowerment (CCEE). In Bengkulu City, the CCEE program is administered by the Development Cooperative of Coastal Communities. One of the main activities of the program is to manage a revolving fund for coastal communities. The outcomes showed that the CCEE program had a positive impact on venture capital improvement and helping the coastal communities to afford their daily need and cover the living cost of the household. Implementation of the CCEE program in Southeast Sulawesi Province also had a positive impact on the coastal community welfare [7]. The CCEE program that had been 
implemented in the Wonokerto District, Pekalongan Regency, Central Jawa dealt with some constraints and problems [8], as follows:

- The delay of the program dissemination to the community at the district, sub-district, and village level.

- The community perceived the program as free assistance and no need to refund.

- Delayed formation of the cooperative resulted in the deferral of the implementation of training for all cooperatives.

- Lack of cooperative knowledge about the selection of the fishing vessel, modification of ship technology, and the importance of a cooler.

- At the training phase, cooperative ability in mastering the material was relatively slow due to the low average level of education.

The study conducted by [8] also measured the level of participation in the CCEE program. The indicators used include the following, (1) the willingness of society to bear the development costs in the form of time and effort in implementing the CCEE program, (2) the people's right to participate in determining the direction and purpose of the program implementation, and (3) the willingness of society to preserve and develop the results of the program.

Although the CCEE program was beneficial to the community, the repayment rate of the revolving fund was only 30 percent [9]. The implementation of the CCEE program in the Banggai District, Central Sulawesi, did not attain optimal results [10]. This is attributed to the program manager's failure to understand the concept of empowerment of coastal communities properly.

The results of the evaluation of activities were classified into six categories, including input, process, output, result, benefit, and impact. The performance indicators used for input were human resources, institution, socialization, received venture capital, training, village assistants, and consultants. In contrast, process indicators include the selection of the location and the target group, the distribution of the program, planning activities, monitoring, and reporting. Output indicators were the performance of production, such as the creation of primary and by-products.

Outcome indicators were revenue and revolving fund productive economy. Similarly, indicators of benefit used the aggregate income, inter-region equity, while impact includes the positive and adverse effects of the program in general. The success of cooperatives is affected by the participation of the members and influences the performance of the organization. Based on the level of participation and health institutions, it is necessary to develop strategies for the effective economic empowerment programs in coastal communities.

Therefore, this research aims to:

- Assess the level of public participation and related factors in maintaining the existence of the CCEE program in the coastal areas.

- Assess the healthiness level of microfinance institutions in coastal areas.

- Formulate an alternative strategy in developing an effective CCEE program in the Bengkulu city.

\section{MATERIAL AND METHODS}

The research method used was a descriptive approach with a case study [11]. The data were divided into two, primary and secondary. Primary data were obtained through interviews with the help of guided questions to guide the direction of the interview using a questionnaire. Secondary data were obtained and collected through the study of documents. Data were obtained from reports, papers, and official documents that complemented primary data.

Bengkulu city was purposively sampled for the location of this study, the capital of Bengkulu Province. In 2002, it developed a microfinance institution under the CCEE program, called Coastal Community Development. The institution later transformed into the Coastal Community Development Cooperative (CCDC), which was the object of this study. Additionally, the beneficiary community of CCDC institution was also the focus of this study. Since the number of beneficiaries is abundant, 61 of them were selected as respondents. However, for the ranking of strategic priorities, 15 people were chosen as the expert respondents.

The descriptive analysis describes the conditions that aim to provide data and information accurately for effective communication and understanding. Descriptive analysis is used to explain the data obtained thoroughly. Primarily, the distribution of the data collected is presented in the frequency table between categories or univariate frequency distribution.

Data analysis for participation involved assessing the level of participation of beneficiary customers or community groups in following the activities undertaken by the CCDC. The analysis was conducted by scoring using a Likert scale consisting of a rating of 1 for low participation, 3 for moderate, and 5 for high. To pursue the research objectives on the factors related to the public involvement, nonparametric statistical tools, specifically the Spearman rank correlation test, was used [12].

$$
\mathrm{rs}=\frac{1-6 \sum_{i=1}^{N} \mathrm{di}^{2}}{N^{3}-\mathrm{N}}
$$

Where:

$$
\begin{array}{ll}
\text { rs } \quad: & \text { Spearman rank correlation coefficient } \\
\mathrm{N}: & \text { number of samples } \\
\mathrm{di}: & \text { the difference between the independent variable } \\
& \text { ranking and the dependent variable ranking of } \\
& \text { the i-respondent } \\
\mathrm{i} \quad \mathrm{i} & \text { i-respondent }
\end{array}
$$

To assess the significance of the relationship, t-test was used with the formula:

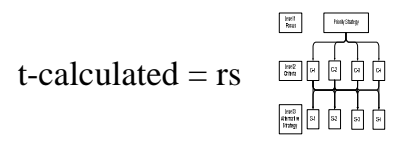

the testing criteria was

- $\mathrm{t}_{\text {calculated }}>\mathrm{t}_{\text {table }}$ or $-\mathrm{t}_{\text {calculated }}<-\mathrm{t}_{\text {table }}$, Ha accepted or Ho rejected. This meant there is a significant relationship between the independent and the dependent variables. 
- $\mathrm{t}_{\text {calculated }} \leq \mathrm{t}_{\text {table }}$ or $-\mathrm{t}_{\text {calculated }} \geq-\mathrm{t}_{\text {table }}$, Ho is accepted or rejected Ha. This means there is no significant relationship between the independent and the dependent variables.

Currently, an analytical tool to determine the health level of microfinance institutions has not been established. Therefore, this research adopted the tools that were used to determine the health level of the Village Financial Management Unit of the Bengkulu Regional Development Project (BRDP) program. Measuring the level of financial unit healthiness was based on indicators assessed by respondents using scores.

Aspects evaluated consisted of the organization of the cooperative with 11 questions, the management of loan funds with 20 questions, and financial administration consisted of three questions. Measuring the health level of financial institutions was based on 34 indicator questions. Each question was answered with a score of 1, 2, 3, 4, or 5. After obtaining the total score of each question, the average scores were grouped by the category rating of the cooperative as follows :

- Average 4.35 to $5.00=$ very healthy

- Average $3.75-<4.35=$ healthy

- Average $3.00-<3.75=$ fit

- Average $2.35-<3.00=$ not healthy

- Average $1.00-<2.35=$ very unhealthy

Analytical Hierarchy Process (AHP) analysis was used to analyze the ranking of development strategies. AHP is a comprehensive methodology capable of uniting qualitative and quantitative factors using models of decision-making hierarchy to rank the alternatives. It uses hierarchical models of objectives, criteria, several sub-criteria, and alternatives for each problem and the decision [13]. Also, it provides an effective structure for decision-making in groups for imposing multi-disciplines in the group thinking and decision-making process.

AHP gives a numerical value to each problem variable, which helps decision-makers to maintain cohesive thought patterns and conclusions. It allows us to structure a system and its surroundings in the parts that interact and synthesizes its units to measure and rank its influence on the whole system [13]. AHP analysis consists of 3 main hierarchies, including focus, criteria and alternative strategies. The results of the study show that the criteria level can be reduced to sub-criteria. In general, the sub-criteria can clarify and facilitates assessment in the form of a paired matrix to achieve focus or goals.

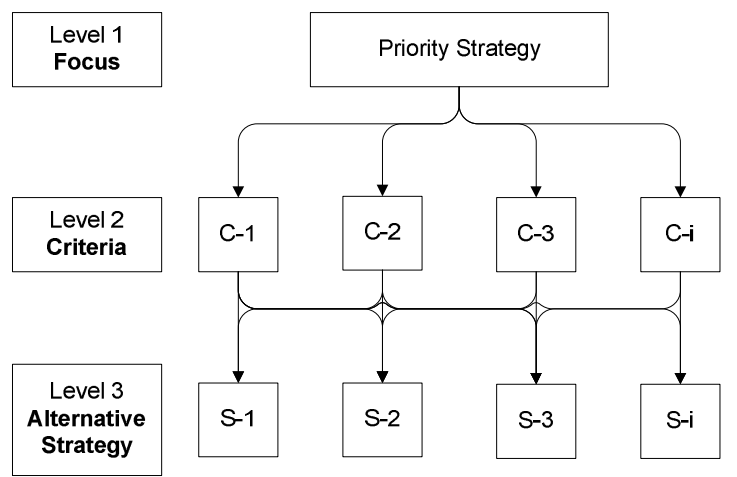

Fig. 1 Decision-Making Process [14]
AHP assessment uses a scale of Strategy starting from 1 to 9 , as follows:

1: equal

3: slightly

5: strongly

7: very strong

9: extreme

2, 4, 6, 8: are in the middle value between two adjacent values. Schematically, the process of decision-making with AHP can be seen in the Fig. 1 [14]

\section{RESULTS AND DISCUSSION}

The level of participation of CCDC members in Bengkulu City was measured by several indicators of activities involving its members. This includes the participation of cooperative members in 1) meetings, 2) the repayment of the loan, and 3) fulfilling the liability. Then, the indicator was categorized by a scoring method using Spearman Rank into low, medium, and high levels. Table 1 shows the results of the member cooperative participation rate.

TABLE I

PARTICIPATION RATE OF COOPERATIVE MEMBERS

\begin{tabular}{|c|c|c|}
\hline No & Participation Form & Percentage (\%) \\
\hline 1 & \begin{tabular}{ll}
\multicolumn{2}{l}{ Meeting } \\
- & Low \\
- & Medium \\
- & High
\end{tabular} & $\begin{array}{l}24.60 \\
42.62 \\
32.78\end{array}$ \\
\hline 2 & $\begin{array}{ll}\text { Repayment } \\
\text { - } & \text { Low } \\
\text { - } & \text { Medium } \\
\text { - } & \text { High } \\
\end{array}$ & $\begin{array}{r}0 \\
1.64 \\
98.36 \\
\end{array}$ \\
\hline 3 & $\begin{array}{ll}\text { Obligation } \\
\text { - } & \text { Low } \\
- & \text { Medium } \\
- & \text { High } \\
\end{array}$ & $\begin{array}{r}0 \\
1.64 \\
98.36 \\
\end{array}$ \\
\hline
\end{tabular}

The level of participation might affect the sustainability of a program [15]. In the meeting, the participation level was moderate, with a percentage score of 42.62 percent. This was because most members of the cooperative were merchants. They cannot attend meetings since they spent most of their time trading. Usually, they were represented by the head of the group during a cooperative meeting.

The types of occupations or sources of livelihood of CCDC members vary. Most of CCDC members work as traders, with a percentage of 62.30 percent. This is also the main objective of the CCEE program, specifically to empower the poor or their members through entrepreneurial activities. So that it is hoped that the loans provided will be used as the capital by members to open businesses and improve the welfare of CCDC members' families. Fishing is the main economic activity in the coastal area [16]. While the percentage of other cooperative members who work as fishermen and entrepreneurs is equal, about 13.11 percent of the total respondents. The other members of CCDC who work as laborer and tailors are 4.92 percent and CCDC members who work as government employees are 1.64 percent of the total respondents.

Nevertheless, the level of participation of cooperative members in the repayment of the loan and servicing the liability was high, with a score of 98.36 percent. Family 
income of CCDC members is one important factor that is closely related to the level of participation of cooperative members in terms of repaying loans.

Income can determine the activities of a person in their daily lives, where they are high-income earners, expenses for necessities will be relatively met when compared to people on low incomes. If the basic needs are met, then it is probable that the residual income will be allocated to repay loans to the cooperative.

Results of the study showed that most income of cooperative members was quite high, from IDR 1,000,000 to IDR. 5,000,000 per month, are 81.97 percent. While other CCDC members earn from IDR 5,000,001 to IDR. 9,000,000 are 13.11 percent, cooperative members who earn less than IDR. 1,000,000 in the amount of 3.28 percent. CCDC members who earn more than IDR. 9,000,000 that is equal to 1.64 percent of the total respondents. The income level can also increase the resilience of a fishermen's household [17]. This is attributed to the high awareness of the need to obey their obligations to repay loans and the other liability as agreed at the beginning. The high participation was the same as community involvement in the CCDC program in Pekalongan Regency, Central Java Province, Indonesia [8].

Awareness of obligations related to education level. Formal education affects the way of thinking and making decisions. Formal education aims to prepare themselves to enter a more active life of thinking in the community and also serves to improve one's skills, intelligence and ability in managing their businesses as well as possible so that the desired goals reached. In addition, the level of education also has an influence on participation because the higher the educational background a person has, the more extensive his knowledge of development and the forms and procedures for participation are given.

The result of the research shows that the formal education of CCDC members are good enough, where 41 percent of CCDC members have received formal education from 10 to 12 years or equivalent to the level of high school education. The cooperative members who received education less than 7 years or equivalent to the level of elementary education are 31.14 percent. Members of the cooperative who received education from 7 to 9 years or equivalent to the level of junior high school education are 22.95 percent. The member's cooperatives that have received education for more than 12 years or equivalent to the level of higher education is 4.91 percent.

TABLE II

VARIABLES ASSOCIATED WITH PARTICIPATION RATE OF COOPERATIVE MEMBERS IN ATTENDING MEETINGS

\begin{tabular}{|l|r|r|}
\hline \multicolumn{1}{|c|}{ Variable } & $\mathbf{t}_{\text {calculation }}$ & $\mathbf{t}_{\text {table }}$ \\
\hline Age & 1.561 & 2.001 \\
\hline Number of Family Member & 1.876 & 2.001 \\
\hline Family Income & $5.432^{*}$ & 2.001 \\
\hline Business Experience & $3.674^{*}$ & 2.001 \\
\hline
\end{tabular}

As a factor affecting the participation in the meetings, the age variable obtained a t-value of 1.561 , which was less than t-table of 2.001 with $\alpha=5$ percent (Table II). Therefore, Ho was accepted, while Ha was rejected. This means that there was no significant relationship between age and the level of participation of members in attending cooperative meetings. The young or old age of the customers was not related to the awareness of the cooperative members to participate in the meetings.

The age factor is important in business activities because age is related to the level of productivity, where the more productive age of a person can increase the production of business activities carried out. Age will also affect the absorption of motivation and technology at work; this is related because the older a person is, the slower the absorption of innovation and acceptance of new technology [18]. Productive age ranges from 15 to 60 years and unproductive age that is from 0 to 14 years and 60 years and above. Based on the research result, the age of cooperative members is mostly in the productive age, namely in the age range from 21 to 60 years which is 93.44 percent. In the productive age, generally, a person has a better ability to think and act to carry out an activity. While the age of nonproductive members or more than 60 years is 6.56 percent.

The number of family members had a t-value of 1.876 , which was less than the t-table of 2.001. This means the number of household members is not related to the participation of members in meetings held by the cooperative. It has no impact on the awareness or desire for cooperative members to attend a meeting.

The number of family members is closely related to the level of family expenditure. The greater number of dependents, the more costs are also incurred. This also affect the level of participation of cooperative members in repaying loans. Based on result of research, most of the number of family members from 4 to 6 people is 73.77 percent. While the number of family members from 1 to 3 people is 24.60 percent. The number of family members is more than 6 people which is 1.63 percent from the total respondents.

Many dependents of cooperative members' households will affect the level of expenditure of household needs, which in turn will affect the activity of members participating in loan repayments. With several dependents of from 4 to 6 people, members try harder to meet their needs and manage expenses to repay loans on time and borrow again later.

Family income had a t-value of 5.432, which was more than t-table of 2.001 with $\alpha=5$ percent. Respondents' income ranges from IDR $1,000,000$ to IDR 5,000,000 per month with an average of income is IDR 2,000,000 per month. This household income is almost the same as the household income of mud crab fishermen on the small outermost island, which is IDR 2,056,425 per month [19].

Therefore, Ha was accepted, or Ho rejected. This meant that there was a significant relationship between family income and the level of participation of members in attending a meeting. A higher household income raises the awareness of members on the need to attend the meetings to keep sustaining the cooperative. In other studies, the level of income affected the participation of fishers in the management of mud crabs [15]. Changes in the income level may negatively affect participation [20].

Business experience had a t-value of 3.674, which was higher than the t-table of 2.001 with $\alpha=5$ percent. The business experience will provide a tendency for those concerned to have relatively high skills. Someone will tend 
to learn from his experience if he does business activities that have been done so that he has an idea of what must be done to increase further business profits.

Based on the data, it can be concluded that most members of the CCDC had business practice less than the last 11 years is 57.38 percent. While the cooperative members who have work experience from 11 to 20 years amounted to 24.60 percent. The percentage of cooperative members who have work experience from 21 to 30 and from 31 to 40 years is equal to 8.19 percent. Cooperative members who have work experience of more than 40 years is 1.64 percent of the total respondent.

This result indicated that Ha was accepted, meaning there was a significant relationship between the business experience and participation in the cooperative meeting. The longer the business experience, the higher consciousness of the need to attend the meeting. This condition is attributed to the need to maintain the continuity of the business and cooperative. Business experience has no significant effect on the management of fisheries resources [15].

Age and the number of family members do not significantly correlate with the level of participation of cooperative members in paying back the loans obtained from the cooperative and the obligation of members. High participation has a positive impact on the performance of CCDC [10]. Also, family income and business experience significantly influence the loan repayment and the fulfilment of the member obligations, as shown in Table III and IV.

TABLE III

PARTICIPATION FACTORS ASSOCIATED WITH LOAN REPAYMENT

\begin{tabular}{|l|r|r|}
\hline \multicolumn{1}{|c|}{ Variable } & $\mathbf{t}_{\text {calculation }}$ & $\mathbf{t}_{\text {table }}$ \\
\hline Age & 0.752 & 2.001 \\
\hline Number of Family Member & 1.776 & 2.001 \\
\hline Family Income & $3.415^{*}$ & 2.001 \\
\hline Business Experience & $3.718^{*}$ & 2.001 \\
\hline
\end{tabular}

TABLE IV

PARTICIPATION FACTORS ASSOCIATED WITH COOPERATIVE MEMBERS' OBLIGATION

\begin{tabular}{|l|r|r|}
\hline \multicolumn{1}{|c|}{ Variable } & \multicolumn{1}{c|}{$\mathbf{t}_{\text {calculation }}$} & $\mathbf{t}_{\text {table }}$ \\
\hline Age & 0.771 & 2.001 \\
\hline Number of Family Member & 1.943 & 2.001 \\
\hline Family Income & $2.764^{*}$ & 2.001 \\
\hline Business Experience & $2.831^{*}$ & 2.001 \\
\hline
\end{tabular}

The findings indicate that an increase in the family income raises the awareness of the need to repay the loan and fulfil obligations to sustain the cooperative. The business experience also influences the level of participation of members in repaying. The longer the business experience, the higher the consciousness members have to repay the loan and fulfil their obligation. This condition is attributed to the need to maintain continuity of business and cooperative by increasing the level of participation of members in repaying the loan and fulfilling their obligations.

Increased level of participation starts by building public awareness of a program or activity [21]. The results of measuring the health level of the cooperative using three indicators with a total of 34 questions are presented in Table V. The average organization indicator was 87.27 percent, which was quite high, and are also influenced by management of the organization [22]. This indicates that the cooperative organization is appropriately governed. The cooperative board exhibited good governance on appointing personnel and compliance function. However, there is no continuous mentoring done by the other parties, including the government.

TABLE V

THE HEALTHINESS LEVEL INDICATOR OF COOPERATIVE

\begin{tabular}{|c|c|c|c|c|}
\hline \multirow{2}{*}{ No } & \multirow{2}{*}{$\begin{array}{c}\text { Organization } \\
\text { Name }\end{array}$} & Organization & $\begin{array}{c}\text { Loan \& } \\
\text { Financial } \\
\text { Management }\end{array}$ & $\begin{array}{c}\text { Finance } \\
\text { Administration }\end{array}$ \\
\cline { 3 - 5 } & & $\%$ & $\%$ & $\%$ \\
\hline 1 & BMP & 87.27 & 91.00 & 93.33 \\
\hline
\end{tabular}

Human resources play an important role in carrying out the CCEE program. Education, knowledge and understanding of administrators involved in the program greatly affect the smooth running of program activities.

Community involvement without differentiating social status becomes a strength in implementing the CCEE program. This is a condition that must be carried out in the community empowerment approach [23]. Socialization and training, which is basic education for the community, provide reinforcement for the speed at which programs are run. The weakness in CCEE program is the absence of institutions others that support the implementation of programs, especially in the management or management of cooperatives.

The loan and financial management indicator describe how members prepare a proposal to the cooperative and how the existing capital is managed. The results showed that the average percentage of the indicator was 91.00 percent, which means there was proper management of finances and loans since the funds involved were not significant.

The institution once managed substantial funds from the community target groups. The primary consideration in financial management is the loan period [24]. However, the institution was relatively unsuccessful, and therefore it deals with funds limited to its capacity.

Determination of the target recipient of the program is in accordance with the wishes of the majority of the beneficiary community. The distribution of aid has been going well where the assistance provided is in accordance with needs and in the right amount. This stage is not optimal due to weak supervision by related parties in its implementation. As evidenced by the fact that there are still many CCDC members who are in arrears on loans that have been channeled through groups. This arrears resulted in the continuation of the revolving program, because only those who have paid off loans at the group level are more entitled to get loans to the CCEE program.

The indicator of financial administration had the highest percentage of 93.33 percent. This means that the cooperative board implements administrative provisions following good cooperative governance, such as cash and loan recording, and preparing financial statements.

There has been an increase in the productivity and quality of production of some community businesses. But there is program output has not been reached optimally. There are still undeveloped businesses, the absence of byproducts and 
the slow acceleration of the number of people who use the program causes output not to be achieved. The slow acceleration of the addition of individual beneficiary communities. The rules of the CCDC does not provide the opportunity to borrow productive economic funds to those who are still in arrears of loans through groups. So that the number of members of CCDC who conduct loan transactions also does not change so much each year. Even though the program implementation stage could not run optimally. The majority of the community (92 percent) still hoped that the economic empowerment program for the coastal community could continue, whether in the same program pattern or in a new pattern that was different from before. This means, this empowerment effort must be continued because it will greatly assist the community in running their business. Whereas 8 percent of respondents thought that empowerment programs such as CCEE program were only for a short period of time during the project. It would not make the community more independent, because of the lack of program implementation efforts to directly supervise how the assistance was used, so that program sustainability was not an important priority.

Therefore, it is necessary to have a design that makes the implementation of the program run optimally. So that the beneficiary community gets alternatives and is able to have the freedom to choose the best alternative for themselves. It can be more dynamic and progressively sustainable. The measurement of the healthiness of the cooperative using all indicators showed the level of health was 4.5 , which is very healthy. This means there is good governance, which includes organization, loan, and financial management and administration.

However, if the cooperative is expected to manage a more significant revolving fund for the economic empowerment of coastal communities, necessary intervention from outside parties, especially technical agencies such as the Department of Cooperatives or the Department of Marine and Fisheries, is needed. Revolving fund programs are suitable for protecting natural resources [25]. The cooperatives still need assistance in developing the organization with the principles of good governance.

Based on the research results on the level of participation and healthiness, the institution can be arranged hierarchically to determine the priority of the development strategy of the CCEE program, as shown in Fig. 2. The structure of the model consisted of 4 levels, including a focus on the $1^{\text {st }}$ level, objectives in $2^{\text {nd }}$, criteria in $3^{\text {rd }}$, and alternative strategies in the $4^{\text {th }}$.

The development strategy of the CCEE program had several goals, including business growth, increasing competitiveness, and improving the welfare of coastal communities. The strategy was selected due to the need to optimize the utilization of existing resources in coastal areas, to increase the availability of capital, and to create cooperatives contribution to the household economy. Alternative development strategies of the CCEE program include diversifying the business, strengthening the institutions, and increasing access to financial capital for cooperatives and coastal communities.

According to the AHP analysis, the priority development strategy for the CCEE program was strengthening cooperative institutions of Coastal Community Development Cooperative (0.632). It targeted to improve the competitiveness of cooperatives (0.576) for CCDC to compete and be the best choice for coastal communities compared to other microfinance institutions. The criteria for the successful development of the program is to optimize the resources owned by cooperatives currently (0.523). The priority strategy of strengthening the institutions can be useful in the implementation if there are the capability and willingness of the government to give attention to the development of cooperative and coastal community [26]. Management of institutions can also apply the principle of reward and punishment to support the success of the program [27].

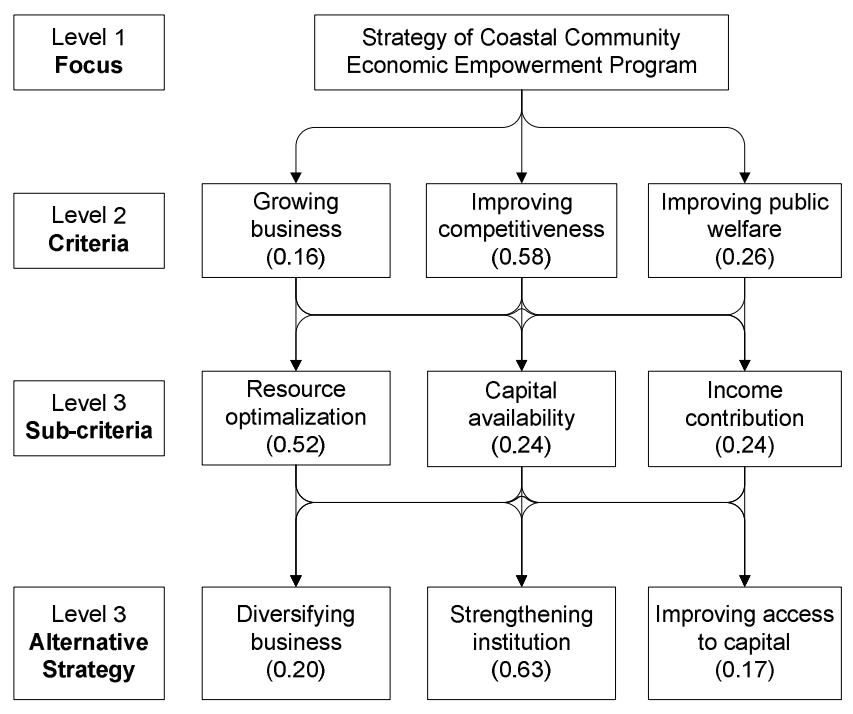

Fig. 2 Priority Development Strategy

\section{CONCLUSIONS}

The participation of the cooperative members' activities, including meetings, loan repayment, and meeting their obligations, are in a high category. Participation is significantly influenced by real family income and business experience. The health level is very high and includes aspects of the organization, management, and financial administration of the loan. Priority strategy in the development of the CCEE program in the city of Bengkulu involves strengthening cooperative institutions to improve the competitiveness of the institution and the optimization of resource utilization. In providing revolving fund and increasing the repayment rate, the cooperative needs to be selective.

\section{ACKNOWLEDGMENT}

This research was made possible through financial support from the Ministry of Research Technology and Higher Education.

\section{REFERENCES}

[1] Badan Pusat Statistik Bengkulu City, Kota Bengkulu dalam Angka 2018. Bengkulu, 2018.

[2] Badan Pusat Statistik Bengkulu Province, Bengkulu dalam Angka 2018. Bengkulu, 2018. 
[3] R. Dahuri, Kebijakan dan Program Pembangunan Kelautan dan Perikanan Nasional, Paper on The Ocean Out Look BEM FPIK. Bogor, 2004.

[4] A. B. Estrella, V. R. Foronda, and M. T. B. Lirag, "Socio-ecological and livelihood assessment of selected coastal areas in Sorsogon, Philippines," International Journal on Advanced Science Engineering Information Technology, vol 5 (4), pp. 339-343, 2015.

[5] H. A. Hidalgo, "Vulnerability assessment of agri-ecotourism communities as influenced by climate change," International Journal on Advanced Science Engineering Information Technology, vol 5 (6), pp. 379-386, 2015.

[6] H. L. Sigalla, "Poverty and livelihood of coastal communities in Tanzania Mainland and Zanzibar", Journal of African Studies and Development, vol 6 (9), pp. 169-178, 2014.

[7] Rostin, "The effect of economic empowerment of the coastal communities and social capital on coastal community welfare", The International Journal of Engineering and Science, vol 5 (2), pp. 12$18,2016$.

[8] S. T. Khasanaturodhiyah, Kajian Partisipasi Peserta dan Kinerja Pengelolaan Program PEMP. Tesis IPB, Bogor, 2002.

[9] I. Cahyadinata, Z. Yuliarso, and B. S. Priyono, "Kajian Keragaan Program Pemberdayaan Ekonomi Masyarakat Pesisir di Kota Bengkulu". Proceeding FKPTPI, Padang, 2015.

[10] Sutomo, Evaluasi Program Pemberdayaan Ekonomi Masyarakat Pesisir. Tesis IPB, Bogor, 2003.

[11] M. Nazir, Metode Penelitian, Ghalia Indonesia, Jakarta, 2014.

[12] S. Siegel, Statistik Non Parametrik untuk Ilmu-ilmu Sosial, Gramedia, Jakarta, 1992

[13] T. L. Saaty, and L.G. Vargas, "Models, methods, concepts and applications of the analytical hierarchy process," Hiedelberg, Berlin, Germany: Springer, 2012.

[14] S. Budiharsono, Analisis dan Formulasi Kebijakan Pembangunan Wilayah Pesisir dan Lautan, PS SPL IPB, Bogor, 2004.

[15] I. Cahyadinata, A. Fahrudin, Sulistiono, and R. Kurnia, "Perception and participation of fishermen in the sustainable management of mud crabs on the outermost small island (Case study : Enggano Island, Bengkulu Province, Indonesia" International Journal on Advanced Science Engineering Information Technology, vol 9(4), pp. 13301336, 2019.

[16] I. Cahyadinata, A. Fahrudin, Sulistiono, and R Kurnia, "Household welfare of mud crab fishermen in small outermost islands. Case study: Enggano Island, Bengkulu Province, Indonesia”, AACL Bioflux, vol 12 (2), pp. 564-574, 2019
[17] I. Cahyadinata, A Fahrudin, Sulistiono, and R. Kurnia, "Food security and multidimensional poverty of mud crab fishermen household in small and outer islands of Indonesia. Case study: Enggano Island, Bengkulu Province", AACL Bioflux, vol 12 (4), pp.1196-1207, 2019.

[18] Fauzi, and J. Arifin. Aspek Kuantitatif Manajemen Sumberdaya Manusia, PT. Elex Media Komputindo, Jakarta, 2007.

[19] I. Cahyadinata, A. Fahrudin, Sulistiono, and R. Kurnia, "Evaluation of mud crab utilization in the small outermost island: A case study of Enggano Island, Bengkulu Province, Indonesia", IOP Conf. Series: Earth and Environmental Science, vol 420, pp. 1-9, 2020.

[20] B.I. Crona, P. Ronnback, N. Jiddawi, J. Ochiewo, S. Maghimbi, and S. Bandeira, "Murky water: analyzing risk perception and stakeholder vulnerability related to sewage impacts in mangrove of East Africa" Global Environmental Change, vol 19, pp. 227-239, 2009.

[21] H. Nanlohy, "Coastal community participation in the management of mangrove areas in The Kotania Bay" J. Fish. Sci. vol 16 (2), pp. 66$71,2014$.

[22] O.A. Balogun, N. Ansary, and S. Ekolu, "Analysis of determinant of revolving credit for small and medium construction enterprises: A case of Gauteng Province", Procedia Engineering, vol 196, pp. 244 252, 2017.

[23] Wrihatnolo and Dwidjowijoto, Manajemen Pemberdayaan, PT. Elex Media Komputindo, Jakarta, 2007.

[24] A. Ziderman, "Financing student loans in Thailand: revolving fund or open-ended commitment?", Economics of Education Review, vol 21 (4), pp. 367-380, 2002.

[25] M. J. Hardy, S. A. Bekessy, J.A. Fitzsimons, L. Mata, C. Cook, A. Nankivell, K. Smillie, and A. Gordon, "Protecting nature on private land using revolving funds: Assessing property suitability", Biological Conservation, vol 220, pp. 84-93, 2018.

[26] S. J. Metcalf, E. I. van Putten, S. D. Frusher, M. Tull, and N. Marshall, "Adaptation options for marine industries and coastal community using community structure and dynamics", Sustainable Science, vol 9, pp. 247-261, 2014.

[27] R.A. Matridi, D. Zuraidi, R. Setyadiharha, E. Sanopaka, D. Effendi, and D.S. Utari, "An evaluation of P3DK (an acceleration of development village program) : A reviewing on failure toward revolving loan fund system in Kepulauan Riau Province, Indonesia", Procedia Social and Behavioral Science, vol 169, pp. 189-197, 2015. 